\title{
WANGKAJUNGA WOMEN: STORIES FROM THE DESERT
}

\author{
Audrey Bolger
}

When Phyllis Kaberry published Aboriginal woman, sacred and profane in 1939 this was a lone contribution to the understanding of the position of women in Aboriginal society for, until then, anthropologists had concentrated almost exclusively upon the role of men. Since then the balance has been redressed somewhat in the publications of other women, both anthropologists and historians, but there is still a need for more research concentrating on women's place in Aboriginal society and particularly on the changes brought about by contact with white Australians. In most cases this contact took place so long ago that it is now only possible to piece together the story of the impact from historical documents. However, in a few cases the contact is very recent and it is still possible for the women themselves to tell us what happened, how their lives and the lives of their children and grandchildren have changed as a result of this contact.

In 1982 I spent five months with the Wangkajunga community ${ }^{1}$ documenting the stories of women who in recent years moved from a traditional life in the desert to residence on pastoral stations. These women now live in a new village, Kurungal, built at Christmas Creek station, which is situated approximately a hundred kilometres south-east of Fitzroy Crossing in the Kimberley region of Western Australia. But they are desert women by origin and forty years ago their people were still living in the desert. The older women thus have clear memories of desert life as well as of their move to the fringes of pastoral stations and eventually to Christmas Creek.

The Wangkajunga move out of the desert took place comparatively recently; most adults over the age of thirty-five were born in the vicinity of the Canning Stock Route and older people lived in the desert until well into adult life. It was probably during the years of the Second World War, when the Canning Stock Route was reopened due to fears of a Japanese invasion of the north, ${ }^{2}$ that many of the present Wangkajunga community had their first contacts with white people and began the movement which eventually brought them to Kurungal. Many older women talk about first seeing white people, bullocks, camels, etc. during this period. Tindale noted that some Wangkajunga people, or south-west hordes of the Kukaja, appeared near Billiluna before 1940 and were known to Capell as Julbre. ${ }^{3}$ Others, referred to by Tindale as Kukaja of the eastern hordes, appeared from east of the Canning Stock Route in 1953 and some of these people were then taken to Halls Creek in government vehicles. ${ }^{4}$

Audrey Bolger is a lecturer in the Department of Social Work and Social Administration, University of Western Australia. She has degrees from the Universities of Papua New Guinea and York.

1 This research was made possible by grants from the University of Western Australia and the Australian Institute of Aboriginal Studies.

2

Bolton 1953:296.

3 Capell 1940:425-30.

4 Tindale 1974:43. 
WANGKAJUNGA WOMEN

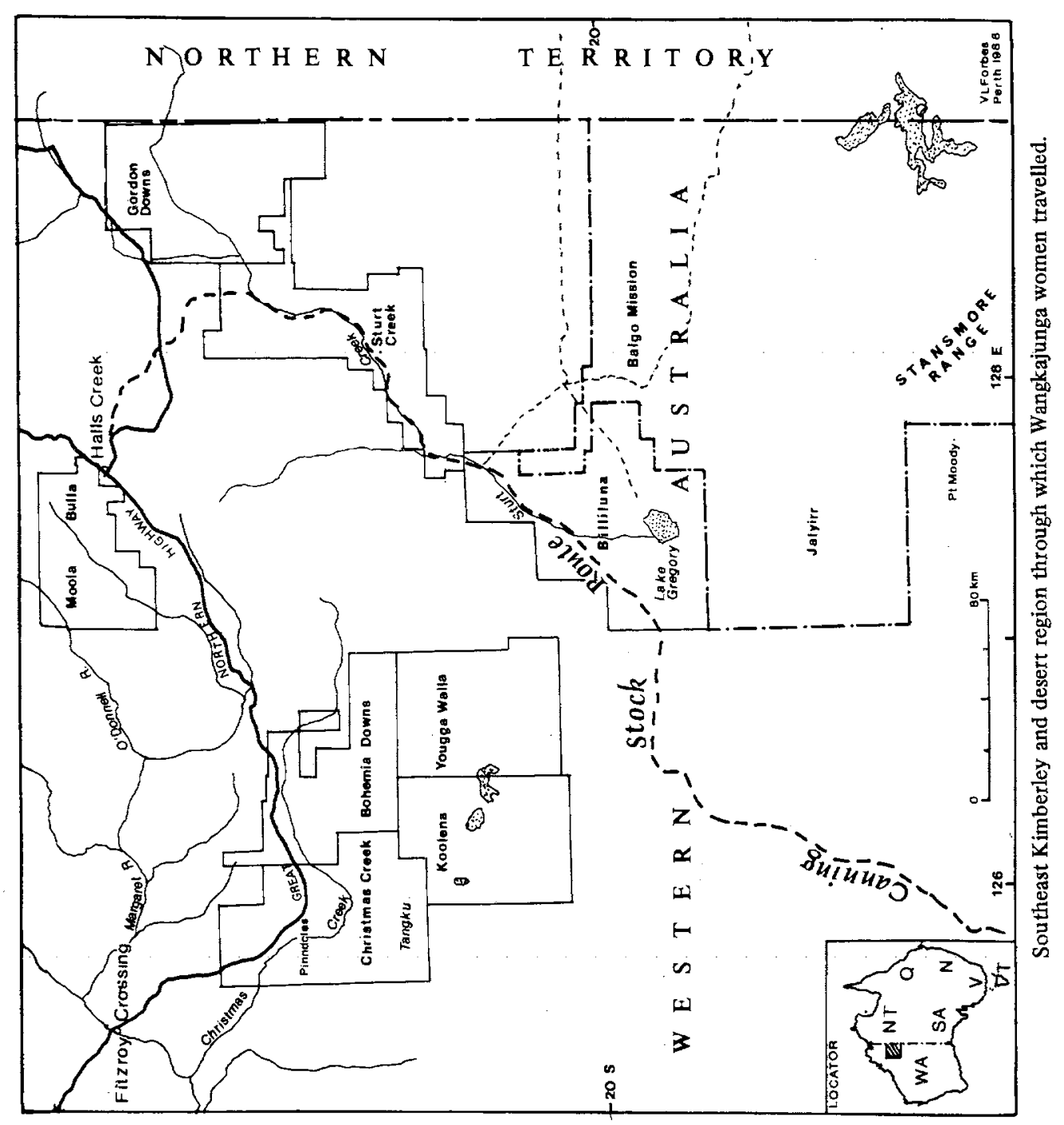


It is not clear exactly why the movement out of the desert took place. Mary Walmajarri people, whose country was farther north than that of the Wangkajunga, were drawn into Billiluna station when it was established in the 1920s, and to Balgo Hills mission when that was set up a few years later. It is quite possible that normal inter-tribal contacts with their Walmajarri neighbours led some Wangkajunga to Billiluna and Balgo. However, other events probably contributed.

In some cases people became isolated and could not survive in the desert when their economic groups were wiped out by pastoralists and police in retaliation for the spearing of bullocks. In other cases desert Aborigines were deliberately sought out by pastoralists who feared the depredations of 'wild blacks' and tried to encourage them to settle near the stations. Finally, there is some evidence that a period of extreme drought in the 1940s forced many people to move north in search of food and water.

Wangkajunga people arrived at Christmas Creek by a variety of routes. Some followed the tracks of relatives and friends in a north-westerly direction and eventually arrived at Koolena, a sheep station adjoining the southern boundary of Christmas Creek which operated between 1947 and 1953. ${ }^{5}$ Here they had their first taste of station life, learning fencing, shepherding and the milking of goats. Those who were still there when the station closed in 1953 then moved north to Christmas Creek, where a number of Walmajarri people and a few Wangkajunga had already settled.

Other Wangkajunga travelled up the Canning Stock Route and arrived at Billiluna station or Balgo Mission. From there some drifted on to other stations and made their way through Ruby Plains, Lamboo and Bohemia Downs stations, eventually arriving at Christmas Creek. Others were forcibly transported from Billiluna to the Aboriginal feeding station at Moola Bulla, near Halls Creek, and later made their own way to Christmas Creek when they heard of relatives being there.

Evidence for the arrival of Wangkajunga people at Christmas Creek is contained in the reports of the Department of Native Welfare where the Aboriginal population of Christmas Creek station is shown as having increased from 100 in 1952 to 180 in 1963. Since then most of them have remained in that area, apart from a period in the early 1970s when many of them were expelled from the station following the introduction of the Pastoral Industry Award. However, by 1978 most had returned to Christmas Creek and in 1980 they were granted an excision of 255 hectares of land about a kilometre from the station homestead. Houses were begun the following year and the first eleven were completed at the end of 1981. In early 1982 Wangkajunga people moved from the old camp by the station homestead to Kurungal village and into the first houses in which they had ever lived.

Older women, particularly, have been through immense changes in their lifetimes, moving as they have from a traditional life-style in the desert to camping and working on stations and finally to the new housing complex in which they live today. Although they have now been at Christmas Creek for many years, older women retain vivid memories of their early lives in the desert and constantly talk about returning to their country one day. The following accounts contain the reminiscences of some of these women who were born in the desert and spent their childhood years and much of their early adult life there. The stories tell of traditional life in the desert, travelling with their parents and close relatives, meeting other 
relatives and people from neighbouring tribes, observing ceremonies. During that time they were also gradually learning their place as women in the society, including the skills necessary for survival in the harsh desert environment.

In addition, there are memories of their earliest contacts with white Australians and of intermittent residence on the fringes of cattle stations or missions before coming to Christmas Creek. From the early contacts they gained some knowledge of the artefacts of white society. Later, as contact became more intense, they learned a little English and a few skills which enabled them to be incorporated into station life to some extent.

The four women whose experiences are documented in this paper were all in their late fifties or early sixties and their stories were told in either Wangkajunga or Walmajarri and translated by one of the young women, Eva Lawford. These women did speak some English but preferred to tell their stories in their own language and were more comfortable and fluent when doing so.

Many of the childhood stories are idyllic. Mary Jarju described life in the desert area west of the Canning Stock Route thus:

Mother and father used to go hunting, with a dog. Big mob of dog we used to have - dingoes. My mother, when she used to go hunting she used to cook the meat out bush and bring it to us when it was cooked. Except for father - he used to bring back raw meat and we used to cook it in the camp. We used to eat and eat and eat. Full up we used to go sleep. We used to live by hunting. Meat used to be there. Every morning we used to eat meat and night-time we used to eat meat.

Next morning we used to go to another waterhole. We used to walk, walk, walk till we used to get to that waterhole. Mother and father used to go hunting again. They used to dig for water. They used to give us drink of water with bark, bark from a tree. I mean coolamon. Until we got big in bush just by eating bush tucker ... That's what we used to do - just walk to waterhole to waterhole, and hunting all kinds of bush tucker. Bush potato, goanna, snake, blue tongue, jarran [a species of goanna] .

Mum used to do the hunting, and Dad, we was small see and it was too far to walk around with them ... We used to play around at the camp and my sister was in charge of us because she was the biggest in the family. Then we went to another waterhole and we found lots of potatoes, bush potato, everywhere. So we started digging them. All of us was digging for that bush potato... Then we went again, walking, walking, and we found lugarra [bush seeds] and we was gathering them ...

Eventually, and, as far as Mary knew, without expecting to, they arrived at Billiluna. Then we saw this lake. The main lake, Blue Lake Paraku. We walk and walk and we came to a house - Billiluna station. One manager was there, Dick Ron. Dick Ron used to manage Billiluna station long time ago, when I was a kid. We lived there in Billiluna with all the other people, stayed there now. Then we went again back to the bush, straight back to Jalyirr.

There were other visits to Billiluna but they were spasmodic. As a young married woman Mary still lived much of the time in the desert and it was some time before she gave up her nomadic life. 


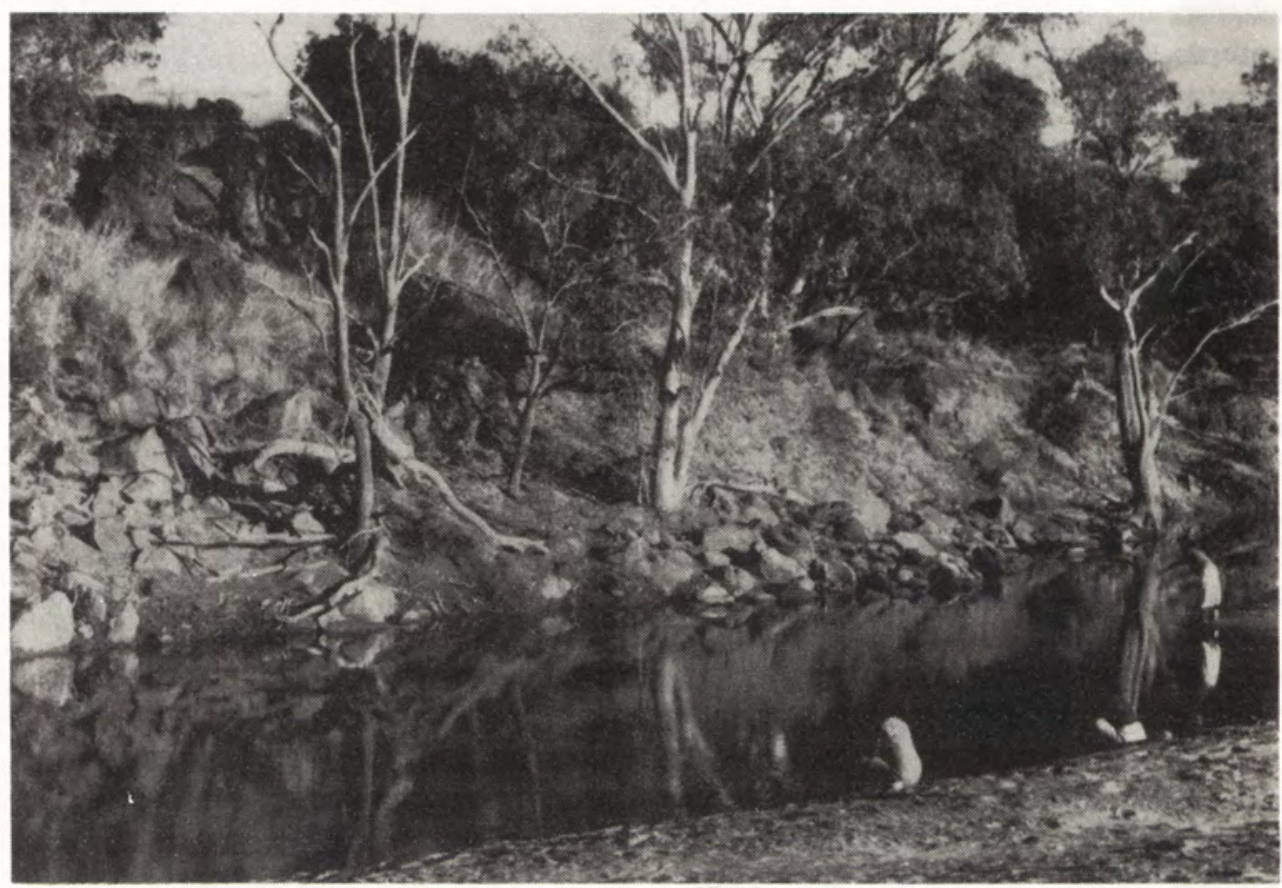

Christmas Creek at Chestnut; Wangkajunga women fishing.

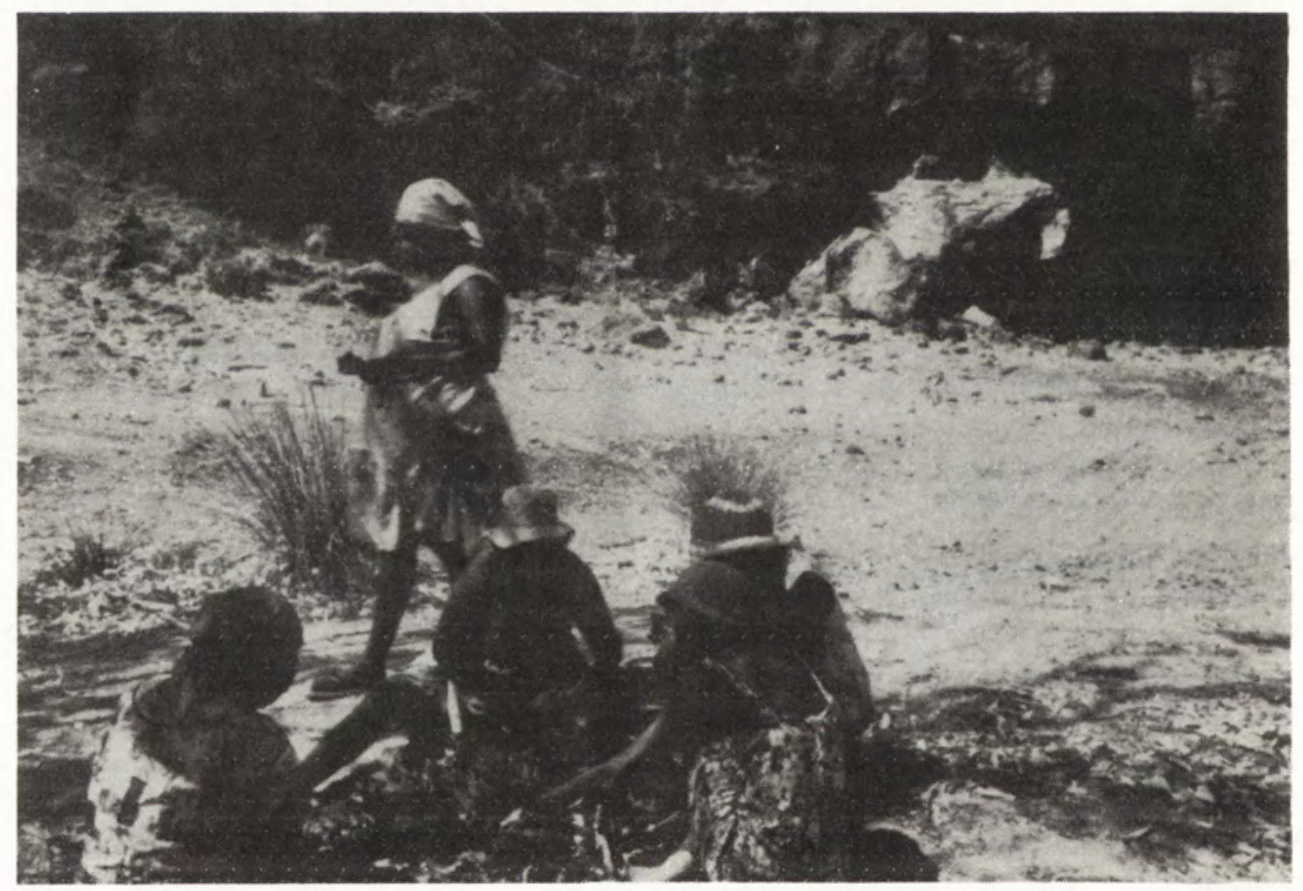

Wangkajunga women sharing a catch. 
Then my father died. When I was walking away, I saw this people, I met them on Canning Stock Route with the cattle. They told me that my father died then. I was sad, crying. Then I went back, went back to Billiluna, stayed in Billiluna little while, then I went nother way, you know ...

From there we went to Government Well - that's right out on Canning Stock Route. Me and my husband we was going from place to place. From there, from Government Well, we went to another rock-hole. We went from there one place called Brengi, me and my husband had dinner there. From that waterhole we went to another place. We was getting near Gordon Downs area but we never go right in because me and my husband we were frightened. Next day they saw us and they sent a couple of men to pick us up. They brought us to Gordon Downs.

I didn't like it in Gordon Downs, I went to Sturt Creek. We stayed there for a little while. We went back to Billiluna. We bin stop there for a little while, in Billiluna. From there Balgo next stop. We bin go from Billiluna to one spring. We bin have water there and we bin go to this old Balgo, old Balgo Mission. Me and my husband was living there now. We bin live there for a lo-o-o-ng time until Gracie was born ... When Gracie got big, she went to school, and my husband died.

Now I'm living with Sundown [her present husband] and I'm living here at Kurungal, Christmas Creek - after Balgo. I'm staying here now.

Although children travelled with their families as they moved camp, all the women told about being left with other children or with grandmothers for much of the time while the adults went on long hunting and gathering expeditions. Sometimes this led to near tragedies as Jeannie James, another of the women, explained:

While my mother was out walkabout, we were playing on the sandhills. And she lit the fire far away in the distance ... We were sitting on the plains, near the grass, and we saw the fire far away ... Then the fire was getting closer and closer ... I was trying hard to pull my little sister, Mary Ann, we were both small then . . Mary Ann was fat, a fat little girl. I was still pulling her away as the fire was getting closer towards us, the fire was getting bigger and coming closer. Our mother came back crying when she saw the fire coming closer - our mother came back from long way and she thought that we were getting burnt. As I was pulling Mary Ann away from the fire, she got burnt - I was small too when I was helping my little sister, Mary Ann. Jimmy Angie [her brother] was there too, he was same size as Anthony [about four years old] . My mother was crying, I started to cry too, she hugged us and was crying with us ... While we were at the camp some of our relatives had a big argument over Mary Ann.

The Law was a vital part of life for these women during their childhood and they have vivid memories of the ceremonies they observed. Jeannie James, who is now the boss woman' at Kurungal, described one of the ceremonies which she saw as a child in the desert:

All the men were throwing water. They were throwing the water and the clouds were forming. Lots of people were coming into that place where we were staying and they were doing wiril marnan and kurtal marnan - for water or making rain. Wiril and kurtal are the two birds that bring lots of rain ... My father and his brothers - that's three altogether - were rainmakers . . . They were doing wiril and kurtal from the west and they did wiril from the other direction, calling all 
the women together, and that was the last dance they did. After that the younger people went out and got darraku [special ceremonial plant food] for the old people and in that way they end the ceremony.

Many of the women's parents and relatives had had little contact with white people but the level of knowledge varied considerably. When Jeannie had her first experience of white people and stations as a small child it was evident that her father already knew a good deal about them:

We stayed in Jalyirr a bit longer and then headed north with our father. We made a camp at Wangkuparongka, the crossing there. Next day my mother and aunty got some goanna and came back to the place where we stayed and cooked it. In the afternoon we headed north and there some people were mustering cattle at Pungkapurtal . . . For the first time we saw a windmill and we were little kids then. We asked our father what that thing was going around and he told us that was a windmill that pumps the water ...

We went over the sandhill and then we followed the river bed. As I was walking I found two watermelon. I ran then to my father and asked him what these two big things were. My father said 'That's a watermelon, you eat it. Bring the watermelon over here.' We busted it - the watermelon was red - and we ate it ...

My family and I came to a stock-camp. As we were coming closer some of our relations found us. While we were at the stock-camp they gave us some tucker and meat to eat. When the stock-camp finished we moved on to old station. We stayed at old Malan and one day people had corroboree, especially for us from the south ... My family and I were new people from bush. We were going with the stockmen and the cooks.

The family still did not settle on a station or mission at that time and for many years Jeannie moved between the stock-camps of the marginal desert stations and the desert proper. Her upbringing and the skills she learnt were almost entirely traditional, and visits to stations, where she was introduced to clothes and to foods such as flour, sugar, tea and beef, remained peripheral to her main childhood and adolescent experiences. In a later story she tells of another bush hazard:

Then one day my sister and I went to get the water, where they were grinding lugarra [seeds] . . I I was a married woman at the time. Our people told us to get water from the place for water called Pilur. As we were coming back there was lots of grass. We were carrying the water with billy cans. We didn't know the snake was coming from the other side. Pilur is a rock-hole... The snake that bit me was a rock snake. Some people were coming towards us and Dora's sister-inlaw called out, 'My cousin has been bitten by a snake.' Some old people said, 'Snake that bit you, you can't get better from that snake.' Dora's sister-in-law said, 'Aunty, can you see the blood on her? See her leg, that's where the snake bit her.'

When we got back to the camp I put the billy of water next to my mother, then I lay down and went to sleep. I thought I was asleep but I was unconscious from the snakebite. My father was close by, he was a mapan [medicine man]. My father got up and felt me, that I wasn't breathing . . After I passed out mapan, which is my father, sucked the wound. He sucked it again, until he 
finished sucking it. That's when I got my breath back again. Then they gave me cold water to drink. And after that I talked like a little child saying baby words

- nyanya - because my mouth was paralysed and I couldn't talk properly ...

As the years passed, Jeannie James and her husband, Jimmy James, spent more and more time on the stations and less in the desert. Her daughter, Julia, was born in the vicinity of Bohemia Downs station about 1940 . Eventually they came to the Christmas Creek area and began working around the Emmanuel stations, of which Christmas Creek is one. Jimmy worked as a windmill-man and fencer, so most of their time was still spent in bush-camps away from the main station homesteads. Jeannie helped her husband with his work but also continued her own hunting and gathering activities, which provided welcome additions to the rations with which they were now provided.

Along with the rest of the community, Jeannie and Jimmy were twice expelled from Christmas Creek station in the early 1970 s and it was only after they returned to the station the last time that they settled down in the old camp next to the station homestead.

A third woman, Violet Jimpirriya, came from Warlpiri country well to the south-east of Wangkajunga country. Her childhood was spent in that area.

My name is Violet Jimpirriya. I lived with my mother, father and my grandmothers, grandfathers and people who were with me and I knew them We wandered around Mungga area which is south-east of Stanmore Range or Point Moody. We lived on porcupines and bush potato, snakes, goanna, bush flour, and all the other tucker in the bush. We drifted round from place to place and I was young then.

We went north and we found all these bush potatoes - little ones they were growing, and we dig them up and we was cooking them there. We stayed there one place now - my father was there, mother and all the people - and we went hunting for porcupine. We killed a lot and I only cleaned mine half way - I left one side because it was too prickly. Then we cooked it and they are really nice and tasty to eat, with a lot of fat.

This life-style continued for many years, during which time Jimpirriya appears to have had no contact with white Australians, nor does she mention hearing stories about them or eating any of their foods. She was still living in the desert after she married and her daughter was born.

Then I climbed up this big sandhill and I left my little daughter sitting under the shade and there I found this bushy-tail rabbit. I killed it and the next morning I found a snake and I killed it. From there we set off again walking and carrying our belongings - our digging sticks and coolamon, water coolamon, and another coolamon with our food and everything. Of course we was walking naked, naked-one we was walking round in the bush. Only with rabbit's fur in front of us and back. All the rest of the body was naked.

Then from there we found these seeds everywhere - black and white and brown grinding seeds. We were busy now collecting them for our food and I told my grandmother to get my little girl, so that us women we can be busy on the seed, collecting them, separating the stone and sand, only putting them clean one on top of the coolamon.

From there we took off again, We bin walk, walk, walk till my grandmother died there - half-way - in one waterhole named Mindarru. She died there and 
I was crying for her you know. Crying, and I hit my head. I hit my head with a stone till blood came out, big mob of blood came out.

Soon after this Jimpirriya's family travelled north and had their first contact with white people. It is not clear why they moved away from their own land - Jimprriya's account gives no indication that there was anything unusual about this - and it colld well be that their usual area of land exploitation was simply extended because of an tbnormally dry season or similar natural event. However, it seems clear from her account thit some of their relatives had already moved north to the stations, and it may be that they were deliberately following their tracks, without realising where they would lead them.

We was walking, all our people same way we was walking. Over the sandhills, just living with bush tucker. We bin walk, walk, walk. We bin look all over and see Balgo Hills. I am from the Warlpiri tribe really and we was coming down to Western Australia. We was nearing, Jalyirr area we was nearing now. We bin have a camp there at Catfish Tank. That place - before that the Kartiya [white people] was shooting all the people there when they was sleeping, before, you know. We got there just maybe after, I think, just after them we got there.

From there we bin find all the Billiluna stockmen. They was mustering cattle and Chumley [a Walmajarri man now living at Pinnacles near Christmas Creek] was there, young man. They had donkeys carrying all the tucker, and camels, and all the piyim there, all the blackfella, and might be two kartiya were there. They were mustering cattle that side, near Lake Gregory. That was all Billiluna area. Oh, they were frightened of us - all the bushmen, bushmen - where's that people from? They bin look now. They're Warlpiri people, different people this lot, naked one. They bin look - oh, they bin know me. 'Oh, Jimpirriya, that young girl, Jimpirriya, that's her, coming up.'

They gave us clothes, that kartiya gave us shirt and things when we had a rest there. Shirt and trousers and we looked funny wearing them We just laugh - laughing at one another. They gave us meat for the first time. We never know, we never eating meat. We just used to porcupine and kangaroo, emu, goannas, snakes, possum, rabbit. We used to those kinds of meat but we had never have bullock meat before. So they gave us salt meat and bullock fresh meat. We ate it and we were sick...

The stockmen then persuaded Jimpirriya's family to go back to the station with them. This was in keeping with government policy of the time, which was to bring all Aborigines in to settlements where they could be civilised and controlled.

We stopped there with them long time. From there we bin go with them now:

'We better go now, we'd better take you mob back to the station.'

'Oh, we'll walk.'

'No, too far, you don't want to walk. Just think about Mungga area, that's too far far away in the Warlpiri side. Too far, we'll take you mob with camel. You have a ride on camel before?'

'No, we did never ride on camel but ... only all the kids can go, all the children. Us people we can walk.'

'Well, all the women, we can take them All the men can walk, O.K.?.

So we agreed to go on the camel. They put us on top, all our gear and everything. All the kartiya gave us a bag for all our bush tucker. There was a bag to 
put all our stuff, kanti [yams] and everything, potatoes. So we put them in and we climbed on that camel - all the kid - might be three men on one camel and all the kid then man on another camel. All like that. Four camels. And the other lot were donkeys. They had all the stockmen's gear. We bin go with the camel now. Slo-o-w walk. Walking, walking, over the sandhill.

We made a camp in one rock-hole . . They gave us flour now, white man's tucker. And we said, 'Oh, ashes, they're giving us ashes.' I didn't know how to make a damper. So the first damper I made, I put a lot of water and I didn't do it properly, you know, make it a bit hard and soft, how they make damper. I threw it on the fire and my sister [one of the women with the mustering team] asked me, 'Hey, what's that you put on the fire, that's not the way to do it. I'll show you how to make a damper.' So she made a damper for me. She fed the other people and me and my little daughter...

So we pack up again. We bin walk-i-n-g, walking, slow walk like camel and we bin all laughing you know when that camel was swaying. We came out in the station now. They left us over that side, under one big gum tree. Because we were different people - and they went to camp, Chumley and them, to tell them we were there, all the bush people. All the people came and visited us from camp. They started crying at us. So we all cried at one another. My grandfather was there, who went before me, my stepfather, stepmother, they went before me, first time.

So we went to the camp and this Billiluna manager asked them to bring us up to the station next morning to give us clothes. So we was living there now in Billiluna. And I started to learn their language, Ngarti. Because when I came from Warlpiri area I was speaking Warlpiri and Ngaripi - two language. But when I came down here to Western Australia I spoke Ngarti, Wangkajunga, Kukaja, that's all I spoke.

I stopped in Billiluna. So we started this, we started walkabout, going walkabout from the station, and coming back to the station. From there we bin get a boy, my granny [grandson], Wilfred Steven from Christmas Creek. They sent him to pick us up, to invite us to the dance. So we all cried, we cried at him then we sent him to Gordon Downs and he pick up all the people from Gordon Downs. They bin meet us and we bin pack all our camels. We was off to Christmas Creek. Walking night and day, same time hunting. We didn't starve. We had a lot of food and we knew the waterhole, the country, the people knew. They showed us people where the waterhole was...

Close up now, closer, we bin look. 'Oh, hill there, hill, Bohemia Downs boundary.' We crossed that river again, Bohemia Downs river, and come out near the station, bit further up. We made a camp there, 'Oh, we better light a fire to tell them people that we are here.' So we light a fire - sign - give them sign that we there near their country, you know. So we keep going, walk-i-n-g, walk walk, walk, walk. We came out at Krakijarti, not far from this hill over here. That little creek there. We got painted there, painted ourselves woneiga [sacred] style - red paint. So that afternoon we would come in.

We saw all the people over there, at Christmas Creek you know. We bin coming in where these State Houses is now, and where that tank is, right there. 


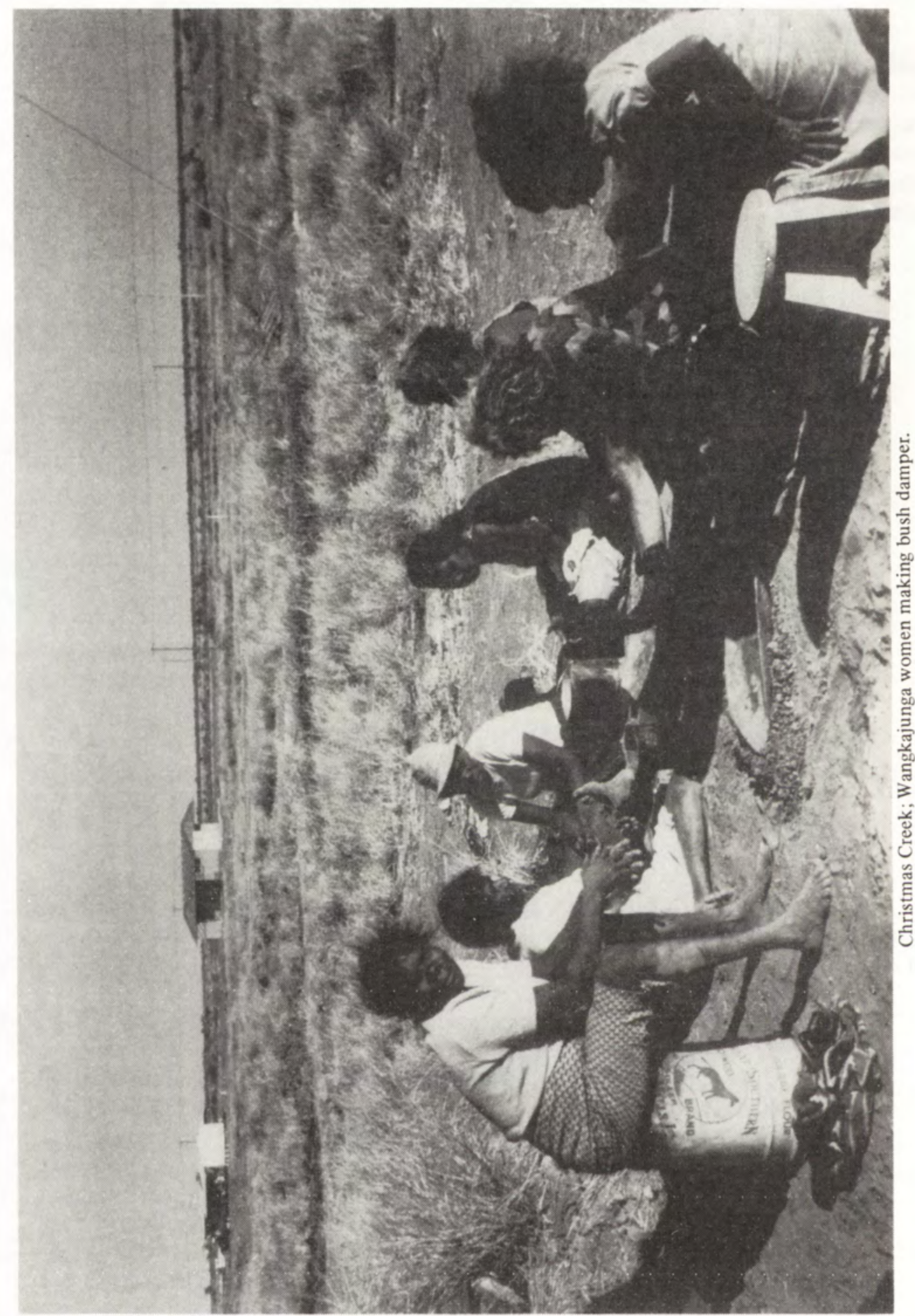


All the people was there on the hilltop. We bin come in dancing, dancing, dancing. We took Wilfred in, gave him to his mother and all his relations at Christmas Creek and they started crying.

And they tell them, 'Oh, some people there Warlpiri people.' So they visited us, looked at us. 'Oh, we know you, Jimpirriya, yes. You coming up from Warlpiri, Kakarung you come out, come up from that way. Yes, well, what you going to do now?' 'I got to stop here at Christmas Creek now.'

So I'm here now. I bin come from my country. Followed my grandfather, with my granny, but my granny died halfway. And I'm right here. I came young woman and I'm getting old here. So I'm going to live here for ever, at Christmas Creek. That is the end of my story.

The fourth woman in this generation, Nellie Janpi, was a Wangkajunga woman belonging to a descent group identifying with the area east of the Canning Stock Route in the region of Tobin Lake. She gave a graphic account of her first contact with white people and of the years when she and her family were introduced to station life.

$\mathrm{Me}$ and my family, my husband and the rest of the people, we were living right at the end of the Canning Stock Route. In one waterhole named No.1 Well, deep well. We were living there hunting food, specially nuts and thing, goanna, and rabbits and all the bush tucker. We were living like that. Then one day we saw a dust coming. We looked, 'Hey, there's something coming up!' Black, it was, all black. We didn't know that it was all the men from Billiluna station. with Wally Dowling in charge. He was the head stockman who used to take cattle from Billiluna across the Canning Stock Route, to Kalgoorlie I think. And we looked at them and we tried to run away. We ran away and hid ourselves, right, but some of the men they started to speak in our language, Kukaja. Because we knew a little bit of Kukaja. They started talking to us now. 'We countrymen. We taking this bullock, pass them over to other lot. Men they waiting over that side there.' So we talked to them and we said, 'Yea, okay then, we'll wait here for you mob.'

Then they took the bullock, and brought out other bullock. So we went with them from No.1 Well. We made a camp there and keep going. Every well we was camping. Men were riding with the horses and us people was walking. We had no children. We walking, was walking with them, when the men was droving cattle across the Canning Stock Route. And Elsie Thomas was a little girl then, and my brother, July Mananta - walking, walking, walking. Same time hunting. And sometimes the men used to give us food. But we didn't know nothing about tealeaf and sugar, and flour or tin stuff. We didn't know nothing.

Walking, walking, walking, walking, walking slowly. When the men used to stop to give the cattle a rest we used to stop. Have a rest too. Sandhill over sandhill, just sand. No trees - little bit of trees - mulga trees. Walking. We came to one well called Government Well. We made a camp there. Slow walk the next morning. Cattle was slow. And we were slow and we went hunting at the same time. We knew the waterhole. Hunting for food, kangaroo. My husband, Bluey Thomas, he used to be a good hunter before. Slowly, the cattle were moving. Slowly, we was walking. And g-o-o-o other side Tangku, straight across to Billiluna station, took: the cattle. We was nearing Billiluna and we made a camp at 
Paraku. That's the main lake. They call it Blue Lake sometime, all the people, when they come from there. But Paraku is the blackfella name. We made a camp there, with the cattle. Made a camp and the next morning we went round it hunting as usual. Hunting for food. There's a lot of tucker there, bush tucker. Like bush nuts, potatoes, jerilkwaja [little potatoes], bush onion, and bush flour, lugarra. We were getting them, filling up our bags or coolamon.

Then they looked at us now, all the Billiluna people. 'Oh, they got some bush people too.' Strangers, they didn't know us. So we stayed there with them. Then we went to Balgo - some of us, all of us, I know, those who came from Canning Stock Route. We bin go Balgo. We lived there for quite a while, when that mission wasn't built. They only had stone houses, antbed houses. Not right up the top where the new Balgo is but the old Balgo.

Then we didn't like it there so we went back walking, walking over that land, over the desert. We didn't have any kids, only some other people had kids. Walking and hunting, looking for water, staying in one waterhole for one night until we got to Bohemia Downs, the new one. We stayed there one night, near the river. From there we went to Tangku, Tangku Spring. There used to be a station there, Koolena. Koolena station and Sam Thomas was the boss there. He had sheep and we was working for him. That's where my son, Mickey Thomas, was born. We lived in Tangku Spring in Koolena station. We lived there all our lives with Sam Thomas. We used to work for him, learning how to keep house clean, men used to learn how to build yards, muster the sheep or take them from one waterhole to another, looking after them. Some men used to go round with Sam to build yards. He used to have an old truck there. And he used to come in to Christmas Creek to get his mail. And we used to go for walkabout to the spring, Tangku Spring, from the station. We used to go there walkabout or for holiday.

Then one day some other people, other bush people, they speared a bullock for Sam and Sam was mad at us too. So he rang the police, he sent a message to the policeman, over the wireless. And when that policeman came, we ran away. We used to run to Tangku Spring and jump in that water, go right underneath, swim and come up the other side in dry land. Inside in dry land. Come out the other side in dry land. That's why the policeman didn't catch us, till after they had other men with them, blacktrackers. So they caught us, took us to the courthouse, to Fitzroy. We didn't know nothing about court. So they let us women and children stay in Christmas Creek and they kept the men in gaol for three days from spearing that bullock.

So now I'm living here in Christmas Creek. When I was bushman we never have no clothes, but when we came here to Christmas Creek, all the people who were living here before us, they came from the bush too but they had clothes on and they showed us how to wear clothes when Victor Jones was manager here.

Long time ago. That is the end of my story.

Although all these women have had to change their life-styles to fit their new circumstances, they have never completely adapted. A few years ago there was no choice but to work at the station, but now all are receiving pensions, either in their own right or as the wives of pensioners, and none have chosen to continue station work. Instead they are happy to spend much of their time in the traditional hunting and gathering pursuits they 
learned in their childhood, sometimes taking along grandchildren to teach them some of their skills.

In addition, they are all important Law women and have contributed to the revival of women's Law which has taken place in the Kimberleys in recent years. In this respect they have responsibilities to teach younger women and also spend much of their time travelling to meetings and ceremonies in other communities. Their lives continue to be as full and satisfying as in those earlier days they recall so vividly.

\section{BIBLIOGRAPHY}

Bolton, Geoffrey, A Survey of the Kimberley pastoral industry from 1885 to the present. MA thesis, University of Western Australia, Perth, 1953.

Capell, A. 'The classification of languages in north and north-west Australia [Part 2]', Oceania 10(4): 404-33.

Kaberry, Phyllis M. Aboriginal woman, sacred and profane. London, 1939.

Tindale, Norman B. Aboriginal tribes of Australia. Canberra, 1974.

Western Australian Department of Native Welfare, Annual reports, 1952-1963.

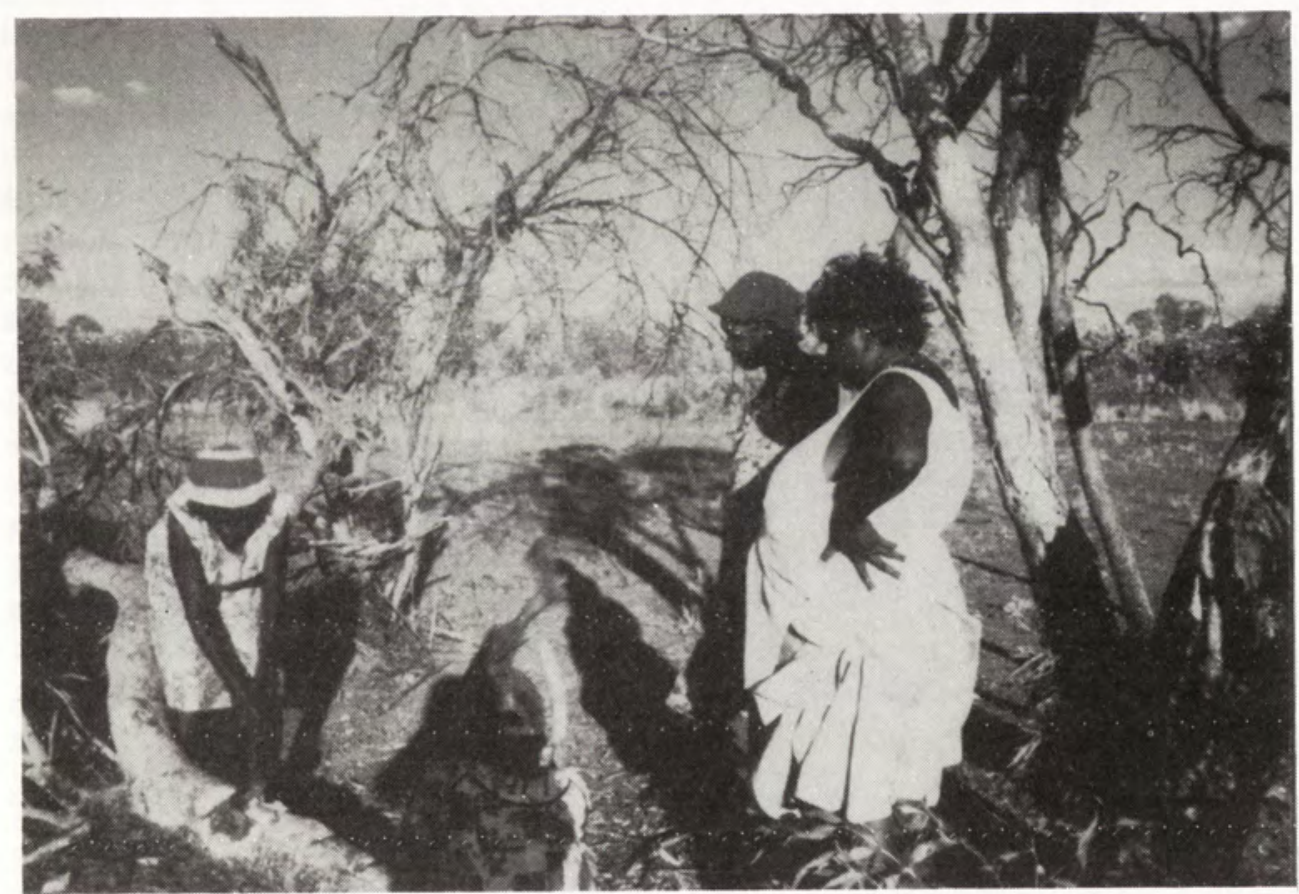

Wangkajunga women collecting sugarbag. 